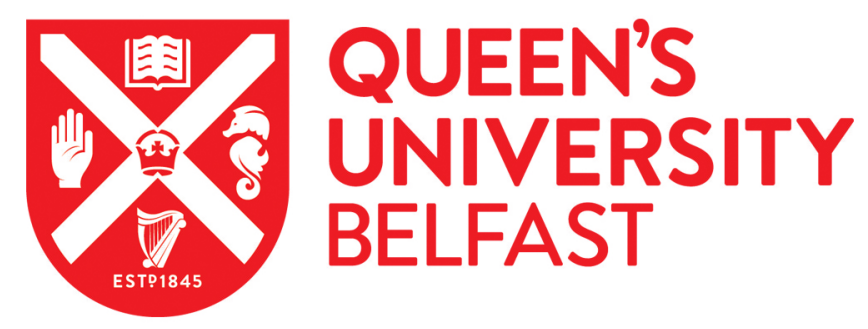

\title{
Introduction to the special issue on the nature of industrial marketing work
}

Palmer, M., \& Truong, Y. (2019). Introduction to the special issue on the nature of industrial marketing work. Industrial Marketing Management. https://doi.org/10.1016/j.indmarman.2019.02.004

\section{Published in:}

Industrial Marketing Management

\section{Document Version:}

Peer reviewed version

Queen's University Belfast - Research Portal:

Link to publication record in Queen's University Belfast Research Portal

\section{Publisher rights}

Copyright 2018 Elsevier.

This manuscript is distributed under a Creative Commons Attribution-NonCommercial-NoDerivs License

(https://creativecommons.org/licenses/by-nc-nd/4.0/), which permits distribution and reproduction for non-commercial purposes, provided the author and source are cited.

\section{General rights}

Copyright for the publications made accessible via the Queen's University Belfast Research Portal is retained by the author(s) and / or other copyright owners and it is a condition of accessing these publications that users recognise and abide by the legal requirements associated with these rights.

\section{Take down policy}

The Research Portal is Queen's institutional repository that provides access to Queen's research output. Every effort has been made to ensure that content in the Research Portal does not infringe any person's rights, or applicable UK laws. If you discover content in the Research Portal that you believe breaches copyright or violates any law, please contact openaccess@qub.ac.uk. 


\title{
Introduction to the special issue on the nature of industrial marketing work
}

\author{
Professor Mark Palmer, \\ Queen's University Belfast, UK \\ m.palmer@qub.ac.uk
}

Dr Yann Truong,

CEREN, EA 7477, Burgundy School of Business

Université Bourgogne Franche-Comté

yann.truong@bsb-education.com

\begin{abstract}
Peter Drucker once remarked that everything degenerates into work, and if it does not degenerate into work, nothing gets done. This special issue presents our vision for generating more analytical attention to the nature of industrial marketing work and to explore ways in which future research can contribute to this nascent research area. In this introductory article we seek to scope out an agenda for taking some of the themes of industrial marketing work further. In particular, the review points to the opportunities within industrial marketing, drawing on the intersections of Margaret Archer's morphogenetic agency approach with the neo-institutional and Computer Supported Cooperative Work (CSCW) fields of study. It then highlights the useful contributions of the papers in this special issue. Our contribution lies in advancing new avenues for researching and, in so doing, ensuring something gets done to research this nascent area.
\end{abstract}

\subsection{Introduction}

A cornerstone of the Industrial Marketing and Purchasing (IMP) Group is that business entities are interrelated networks (Halinen, Salmi \& Havila,1999). The concept of networks is accordingly one that simultaneously emphasises both 'net' and 'work'. There is therefore a natural synergy between work-based perspectives and industrial marketing studies. However, it is fair to say that there is more attention on 'net' centred research rather than the 'work' centred research - a point well made by several industrial marketing authors (Finch \& Geiger, 2011; Mason, Friesl \& Ford, 2017). This special issue presents our vision for rebalancing this and giving more analytical prominence to the nature of industrial marketing work. The seven papers in this special issue are thus an important and promising step towards building on this industrial marketing work agenda. The task now, of course, is to go further. 
This introduction commentary will therefore scope out topics for an industrial marketing work agenda and also highlight some of the most promising ideas from this special issue. In this editorial we comment upon themes that emerge from the papers included in this issue: the nature of industrial marketing work, the role of work agency and the challenge of researching work. To do this, we draw upon a number of research literatures: Gilbert Ryle's question 'What does work consist of?' helps us to 'zoom in' on what people actually do in industrial marketing work, while Margret Archer's (1995) morphogenetic cycle approach helps us to frame industrial work agency in terms of the reflexive nature of that work; the neo-institutional and Computer Supported Cooperative Work (CSCW) perspectives also shed further conceptual light on the nature of that work. The next section initially considers the setting for the 'turn to work' perspective. The paper concludes with outlining the selected papers within the special issue.

\subsection{Setting the context and the nature of industrial marketing work}

The focus on work in this special issue reflects an important and traditional emphasis by industrial marketing research as well as engaging with the 'turn to work' perspective that has gained considerable traction in the broader management fields recently (Phillips and Lawrence, 2012; Okuysen et al, 2015). Reviews of recent studies on industrial markets reveal an increasing move towards an explicit focus on a work-based approach (Azimont and Araujo, 2010; Darr, 2011; Finch and Geiger 2012; Palmer et al, 2015; Palmer et al 2017; Mason, Friesl \& Ford, 2017). The 'work turn' can be observed across the broader management disciplines. For example, boundary-work (Gieryn, 1983), work as talk (Gronn, 1983), translation work (Latour, 1992) and institutional work (Lawrence, Leca and Zilber, 2013), have all become important research avenues in recent years. Against this background, the papers in this special issue aim to builds upon encouraging developments in industrial marketing research, notably recent studies on 'classification devices' (Azimont and Araujo, 2010), 'meaning-making work' in sales supervisor relationships (Fock, Yim \& Rodriguez 2010), 'objectification' (Finch and Geiger 2012), 'institutional boundary-work' (Palmer et al 2017) and 'conceptualisation work' (Mason, Friesl \& Ford, 2017). These studies provide a useful context and starting point for exploring the nature of industrial marketing work. While there are some similarities here with more recent studies in the broader management literature (Okuysen et al, 2015), we argue that it ought not to be the exclusive province for other business disciplines to study 'work' - if nothing else, marketing comprises work! Notably, in the human resource/industrial relations literature, the topic of the work labour has been given much attention (Kalleberg, 2009). Recent years has witnessed a body of research associating work with practice theory (Feldman and Orlikowski, 2011). Equally noteworthy, neo-institutional explanations bring attention back to inhabited nature of working institutions. Here, work is what gets things done and accomplished

- the 'intelligent, situated institutional action' (Lawrence \& Suddaby, 2006: 219). Studies have presented interesting findings in relation to the political, technical and cultural work of institutionalizing management fashions (Perkmann and Spicer, 2008) and the practices of 'boundary-spanning' in renegotiating forestry practices (Zietsma and Lawrence, 2010). Although not exclusively concerned with institutions per se, institutional conceptualizing helps with understanding the nature of the IMM work and also runs throughout many of the papers in the special issue. Important insights are also evident from Computer Supported Cooperative 
Work (CSCW) research studies and are examined in more detail below. We believe that the nature of industrial marketing work can be better understood through the application of these theoretical perspectives.

An important signpost where industrial marketing work is concerned is the theoretical question raised by Gilbert Ryle: 'What does work consist of?' (see Schmidt, 2010 for a useful summary). This central question helps us to 'zoom in' on what people actually do in industrial marketing work. Drawing on Gilbert Ryle's argument Schmidt (2010) notes that "there was no general answer; some sorts of work are done with some sorts of tools, others with other sorts. But sometimes the same work might be done with alternative tools. Some work does not require tools at all.... Not all work is for pay; not all work is unpleasant; not all work is tiring." [pp. 260]. According to Schmidt (2010), Gilbert Ryle discusses the concept of 'working' as polymorphous in the sense that the application of the term 'working' does not imply the performance of any specific activity. There is, therefore an understanding that to frame and categorize a given activity as work involves implicit references to motive, circumstance and identity. For example, that 'the marketer is working again on an issue', or that 'marketing department is focused on a particular project', or 'the marketing department and sales department are working together' or 'the marketer's work is not always recognised in the boardroom'. That is, how is the industrial marketing work identified in the broader system the department or the strategic business unit, the subsidiary, the firm, or amongst the network of channels of distribution (i.e. agents, wholesalers or resellers). Most, if not all, marketing projects use sociomaterial tools, whether technology-specific (e.g. social media, spreadsheets, powerpoint), or marketing-specific tools (e.g. sales management software, marketing audit, service quality, strategy and competitor analysis). Thus there is a clear opportunity for B2B researchers to explore further the role of material technologies, market devices and tools in industrial work, particularly by building on Orr's (1996) classic study of repair work of photocopiers, or Notteboom \& Rodrigue's (2008) study on the container in the shipping industry, or Cochoy's (2009) study on the shopping trolley.

The term 'work' also denotes what social actors do to sustain social order (Cochoy and Dubuisson-Quellier, 2013). Here, work performance involves more than outcomes (e.g. market share, category or product sales); performance is also about how marketing actors 'perform' their roles. This performative aspect of work is critical for ensuring maintenance, for example, adherence to rules (e.g. a buyer's terms of reference or tender bids), or reproducing these rules and existing norms, or marching boundaries for network influence (Palmer et al. 2017). The notion of industrial marketing work can also theoretically cover the routine effort involved doing the work, for example, the activity of organising and co-ordinating events. Here, research might adopt a tight empirical focus, often on 'temporally specific' events (e.g. trade fairs) (see Hedaa and Törnroos (2008). There is particularly rich potential in studying short 'episodes' of work, which could include, for example, the ordinary or mundane troubles associated with service maintenance, handling and resolving the tensions that could arise between and dealing with an industrial buyer or seller. Thus the focus is on activity and effort rather than accomplishment. These efforts, for example, can be seen in relation to the work in privileging or directing repairs to institutional pillars (i.e. reinforcing the regulative, normative, cognitive bases).

An overlapping idea central to industrial marketing work concerns its discursive nature - either in terms of how actors interact (e.g. email, meetings, workshops), the persuasive rhetoric 
employed, or written discourse (e.g. a contract, report). Industrial work-as-discourse requires capacity to access appropriate discourse (e.g. product specifications, white papers, digital content), and skill in using it. By virtue of the boundary-spanning role of marketing, being able to navigate institutional-specific, sectoral-specific as well as departmental-specific language (e.g. R\&D, accounting) may serve to progress the industrial marketing work agenda. Indeed, strategic 'net' influence and even work tenders may be won or lost through discursive dexterity and deploying marketing discourse skilfully. How do industrial marketing managers frame strategic issues, organise sectoral interest, build strategic visions, pitch R\&D projects, collaborate in market-making, negotiate agent sales territories or distributor deals and so on? What are the dominant discourses within an industry, workshop, firm, department and how does that impact the nature of the work? Sometimes a distinction is made when they individuals say, 'enough talk, let's get to work!' But what happens when talk is a central concern to industrial marketing work? Thinking through Gilbert Ryle's ideas raises a series of questions of how 'individualised pockets of work' as well as 'same work practices' emerge over time and space (Leonardi \& Barley, 2008), not least for improving competitiveness when establishing standards, consistency and uniform industrial marketing work practices. Theoretically, moreover, it brings out the purposeful nature of industrial marketing work and how agency is produced. Turning to this point, it is helpful to deepen the conceptualisation of industrial marketing work agency to understand the dynamics through which work takes place.

\subsection{Agency of industrial marketing work}

The IMP tradition has completely appreciated the disseminated role of agency beyond the buyer-seller dyad (Halinen, Salmi \& Havila,1999). The concept of work highlights the intentional actions taken, some highly visible and dramatic, but also that which is invisible and mundane, as in the day-to-day adjustments, adaptations and comprises (Lawrence et al., 2013). Within neo-institutional approaches, a focus on work reverses the emphasis of how institutions govern action by exploring how actions affect institutions, especially the practical actions by which institutions are created, maintained and disrupted (Lawrence et al., 2013). Selznick (1949) indicated that institutions can acquire a 'life of their own' if they are co-opted by agents with particular commitments that go beyond the original work endorsed by the institution. This inside-out view of institutions opens up the study of the inhabited nature of institutions, how such institutions work to reproduce or elaborate, but also theoretical questions relating to position, rank, status and the role. The contributions of the special issue also point to role of agency not only in terms of market change but also in terms of market stability - conforming to the status quo. How do industrial marketing managers' roles and work practices interplay? How do network or channel roles or status potentially change or remain the same in the face of industrial market-driving work? In this section, we draw on Archer's (1995) morphogenetic cycle can frame research opportunities for further conceptualising of industrial marketing work agency. Archer's (1995) morphogenetic cycle approach provides a process understanding of agency - see figure 1. This view of agency is a cyclical process involving three parts: at time $\mathrm{T} 1-\mathrm{T} 2$, existing structures condition the interpretations and actions of managers by shaping the situations in which they find themselves. At time T2-T3, managers interact to pursue their projects, activating both structural and personal properties. Structural elaboration (morphogenesis) or reproduction (morphostasis) at time T3-T4 are consequences of these interactions, and provide the beginning (T1-T2) for a new morphogenetic cycle. Each morphogenetic cycle distinguishes three broad analytical phases. 


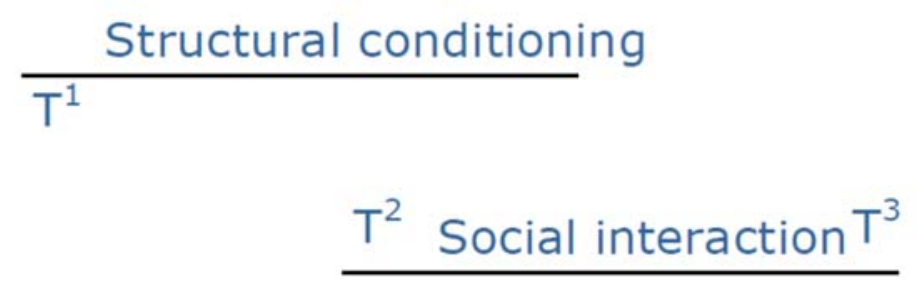

Structural elaboration

$\mathrm{T}^{4}$

Figure 1: the morphogenetic cycle: adapted from Archer, M (1995) 82

Archer's morphogenetic approach highlights the role of reflexivity, which arises from individuals' personal identities and is defined as a mental ability: 'our power to deliberate internally upon what to do in situations that were not of our making' (Archer, 2003: 342). Here, Archer (2003) refers to 'communicative reflexive modes' where, for instance, industrial marketing managers favour work continuity (e.g., Key Account Management, supplier maintenance and customer relationship management). By contrast, she refers to a 'autonomous reflexive mode' where, for instance, industrial market managers favour discontinuity in work, searching for future work opportunities (e.g., new business development, new product development, in technology or market driving strategy environments). In such contexts, how do industrial marketing strategies present themselves as dynamic, while also enduring and stable? How industrial marketers reflexively engage with new technologies, market driving channel disruption, or marketplace innovation? B2B research appreciates how macro and meso-level network issues - such as group alliances, coalitions, industry associations or firm cohorts - influence micro-level, individual work agency. As individuals rarely transform their contexts alone, studies on concepts such as collaborative institutional agency (BridwellMitchell, 2016), collective institutional entrepreneurship (Wijen \& Ansari, 2007) and distributed agency (Garud \& Karnøe, 2003) are illustrative how cohort dynamics could investigate the nature of IMM work. Given the imperative for change in industrial marketing, there is therefore much to be gained by $\mathrm{B} 2 \mathrm{~B}$ research providing nuanced accounts of the agency of industrial marketing work, as the contributions in this special issue do, and many others have done with the agency of technology and institutional regimes such as family, government, trade and professional associations, fashions as well as broader societal pressures.

\subsection{Industrial marketing work and $\mathrm{CSCW}$ insights}


An important task of this special issue is to scope out an agenda for taking some of the themes of industrial marketing work further. In addition to the ideas discussed in the preceding sections, we also draw on the valuable insights from the CSCW studies to provide some initial guidance. While there are plenty of areas, for illustration, we focus on three.

Awareness work. A central concern of CSCW has been to understand the 'mechanisms' and 'coordinative' work practices. How do individuals coordinate with others their work activities that allow others to become aware of their actions? There are synergies with this question in understanding sense-making (Möller, 2010), the implementation of market orientation across departments (Johnson \& Sohi, 2017), institutional boundary-work (Palmer et al. 2017) and market-making opportunities (Mason, Friesl \& Ford, 2017). While there are many things that one could be aware of within an environment, those issues that are relevant or pressing to the situation become notable and open to research scrutiny, notably by studying routines, interruptions and events. In an illustrative study on geologists, Frodeman (1996) identifies similarities between sites through 'visual intelligence' heuristic devices (e.g. contrasts, patterns and aberrancies). Future research could aim to understand how various sales technologies mediate best-practice in work and also 'support' work awareness (for example, role of spaces and material connections). Also significant, but much less acknowledged is the way that the work of enforcing industry or firm rules is undertaken, for example, for buyers in repairing breaches of the rules of engagement by supplier competitive jostling or in the face of technology disruption. Drawing on Schutz and Luckman (1989), Campagnolo, Pollock \& Williams (2015) posit the notion of appresentation work - the process of making available to participants 'what lies spatially and temporally beyond their reach' (p.151). For example, where industrial suppliers and buyers make sense of and convey some confidence about matters in which they have no direct experience, perhaps in relation to the future evolution of sales technology. This form of work links between what is locally present and what is not. As Husserl suggests, "what is not present is 'always' and 'necessarily' implicated with what is immediately apparent and determines the sense of what is seen" (Husserl, 1960 [109] cited in Campagnolo, Pollock \& Williams, 2015).

Articulation work. The concept of articulation work informs much CSCW research (Schmidt $\&$ Bannon, 1992). Drawing on the work of Strauss $(1985,1988)$, articulation work is described as "... work that gets things back 'on track' in the face of the unexpected, and modifies action to accommodate unanticipated contingencies" (Star and Strauss 1999: 10). Articulation work takes into account the key attribute of all work, "it is impossible, both in practice and in theory, to anticipate and provide for every contingency which might arise in carrying out a series of tasks. No formal description of a system (or plan for its work) can thus be complete." (Gerson and Star 1986: 266). For work to get done, then, the variations, deviations, and inconsistencies must be resolved via what Pollock (2005) refers to as 'workarounds' and the 'here and now'.

Invisible work. Another important theme from CSCW studies relates to way that work is often unacknowledged (Star \& Strauss,1999). Nardi and Engeström (1999) describe four kinds of invisible work: (i) work done out of view of others, (ii) routine or manual work requiring judgment and skill not acknowledged, (iii) work done by people who are not valued, and (iv) work that is not part of anyone's job description, but critical to getting things done. As Star and Strauss (1999: 20) point out, "[i]f one looked, one could literally see the work being done- 
but the taken for granted status means that it is functionally invisible." For example, a supplier ensuring cross-compliance in securing a product listing. This research perspective also orients us to the inhabited nature of institutions as well as the multiple perspectives of differently positioned actors, perhaps across a business network. Suchman (1995) discusses the complex tradeoffs involved in making work visible. On the one hand, visibility can mean legitimacy, rescue from obscurity or other aspects of exploitation. On the other, visibility can create reification of work, opportunities for surveillance, or come to increase group communication and process burdens.

Whereas the above research areas are ostensibly mediated on the axes of technology, a key strength and a further challenge for the 'turn to work' agenda is to be sensitive to industrial marketing work situations. In sum, awareness, articulation and invisible work, we argue, plays a key role in industrial marketing management. By focusing more explicit attention on the nature of IMM work, insights from the CSCW perspective can highlight new work activities but also reinvigorate the industrial marketing work agenda. In the preceding sections we have already alluded to the contributions in this special issue, but in the next section we will introduce each paper briefly.

\subsection{Contributions to the special issue}

The special issue papers all address a range of topics drawing on a work perspective, with diverse conceptual backgrounds, including literature on identity, institutional theory, discourse, decoupling and strategic orientations. The issue opens with a paper by Curtis investigating the individual identity work processes of digital industrial marketers as they make sense of their corporate identity when updating Twitter accounts. This paper picks up on a key theme of the work perspective - the agency produced by the tensions experienced by the digital industrial marketers during the course of their digital work. It demonstrates that identities are in-themaking and require ongoing work to maintain.

Michela, Saucedeb, Pardoc \& Fenneteaud's paper acknowledges the agentic side of institutional maintenance work and the complex interplay between intermediaries and positioning changes within a business network. This paper foregrounds the agency of actors' purposeful efforts to maintain the status quo, while also acknowledging how other actors attempt to disrupt the existing 'rules of the game'. Institutional work is required not only for retailers' quest to change and to disrupt the position of wholesalers, but also, as Michela and her colleagues show, for maintaining stability. This resulted in new positions for wholesalers: the 'troubleshooter' and the 'quality enhancer'. Agency in this sense is elaborated through business-to-business interactions. In institutional terms, this study brings the idea that institutional arrangements are unanticipated consequences of interactions between actors - a point advanced in the CSCW literature.

Getting things done is an important aspect of industrial marketing work. Extant literature often emphasise fixing or repairing gaps that emerge in industrial project implementation. Jabbouri, 
Truong, Schneckenberg \& Palmer's paper in this issue shift the gap implementation question forward to understanding firms' responses to the pressure of institutional contradictions to maintain project implementation gaps, whilst simultaneously complying to the institutional regime. They identify three types of means-end decoupling work in R\&D project implementation: 'work on' causal complexity, 'work at' behavioural invisibility, and 'work with' practice multiplicity. In addition, they uncover six dynamic micro-mechanisms that collectively influence the making and nature of means-ends decoupling work and therefore serve to allow for the fluid switching of work as the institutional conditions permit.

The next two papers consider the discursive nature of industrial marketing work. While talk with clients might not seem like work - both Nilsson's as well as Blanc \& Huault's study advance the argument of talk-as-work, indicating that such activities are particularly important when facilitating, for example, interdepartmental or buyer-seller cooperation and negotiation. Nilsson's paper employs a rhetorical perspective to the study of marketing work in an industrial context. This paper discusses how marketing professionals employ versatile and controversial talk to enact contradictory selves for persuasive purposes. In so doing, it provides a rich empirical illustration of the nature of everyday activities marketers are part of in organisations that deal with complex professional services. Taking an institutional maintenance perspective, Blanc \& Huaul point to an important and often taken-for-granted institution in the workings of industrial markets - language. Blanc \& Huaul empirical paper provides a very interesting complementary contribution to that of Nilsson's by showing the specific vocabulary can be mobilized to work on multiple agendas and interests to preserve and maintain the market status quo. Studying the market of France's recorded music industry, this study shows how incumbents engage in discursive work to maintain their interests when faced with an institutional jolt. This study showed how the dual process of word repetition and incorporation were relatively empty and ambiguous floating signifiers. This paper represents a promising avenue to better account for the significance of vocabulary in the institutional maintenance of markets.

The final two papers draw attention to a complementary strategic perspective for understanding industrial marketing work. Nenonen, Storbacka \& Frethey-Bentham's paper focus on a macro index understanding of what they refer to 'market work' - defined as purposeful efforts by a focal actor to perform and transform markets. This study demonstrates both the scope of index market work as well as the actual mechanisms that enables firms to identify, benefit from, and curate markets in-the-making. The authors raise interesting questions relating to the work done to conceptualise and represent markets with indexes, related marketing responses to such conceptual rankings, how index curation work helps shape placings on these measures, as well as how industrial market actors wield influence over the ranking criteria and the wider market. Taking a different business interaction work focus, the final paper in the special issue by Chaney, Carrillat \& Zouari's adopt an inhabited institutions approach and provide a range of insights into a higher order, firm level, institutional orientation. The findings reveal that institutional orientation is composed of three dimensions: the key institutional customers' concept, the political and institutional perspective and market legitimacy. By highlighting different dimensions as well as scoping out the relationships among these dimensions, this 
paper should be an important contribution to future research considering how business orientations can change or stabilise B2B work.

\subsection{Conclusion}

A central tenant of the interaction and business network approach is work. The aim of this special issue is to scope out further directions for understanding a work perspective of industrial marketing and to offer guidance on how to move this understanding forward. In doing so, suggests that we should pay more attention to the 'work turn' to understand industrial marketing management. In this paper, we highlight a range of themes that enable us to think about the nature of industrial marketing work and how it varies a lot. In conclusion, we present a range of research intersections between Margaret Archer's morphogenetic agency approach, neo-institutional and Computer Supported Cooperative Work (CSCW) studies, which could be more extensively applied to explain a variety of industrial marketing work. We hope we have made apparent the need for more research in this direction and would like to thank the reviewers' for providing feedback on the papers submitted to the special issue. Industrial Marketing Management welcomes further studies that contribute to this industrial marketing work agenda and to ultimately make managers' work more effective.

\section{References}

Archer, M. S. (1995). Realist social theory: the morphogenetic approach. Cambridge, UK: Cambridge University Press.

Archer, M. S. (2003). Structure, agency and the internal conversation. Cambridge, UK: Cambridge University Press.

Azimont, F. \& Araujo, L. M. (2010) The making of a petrol station and the "on-the-move consumer": classification devices and the shaping of markets. Industrial Marketing Management. 39, 6, 1010-1019.

Barely, S. R. \& Kunda, G. (2001) Bringing Work Back In. Organization Science 12(1) 76-95.

Bridwell-Mitchell, E. N. (2016) Collaborative Institutional Agency: How Peer Learning in Communities of Practice Enables and Inhibits Micro-Institutional Change. Organzational Studies. 37(2) 161-192

Campagnolo, GM, Pollock, N \& Williams, R.(2015).Technology as we do not know it: The extended practice of global software development' Information and Organization, 25, 3. 150159.

Cochoy, F. \& Dubuisson-Quellier, S. (2013). The sociology of market work. Economic Sociology. The European Electronic Newsletter, 15 (1) 4-11.

Cochoy, F. (2009). Driving a shopping cart from STS to business, and the other way round: On the introduction of shopping carts in American grocery stores (1936-1959). Organization, 16 (1) $31-55$.

Darr, A. (2011). Sales work and the situated constitution of legitimate economic exchange. Work, Employment and Society, 25(3), 506-521. 
Feldman, M. S., \& Orlikowski, W. J. (2011). Theorizing practice and practicing theory. Organization science, 22(5), 1240-1253.

Finch, J. \& Geiger, S. (2011). Constructing and contesting markets through the market object. Industrial Marketing Management, 40(6), 899-906.

Fock, H. Yim, F. \& Rodriguez, M. (2010). The effects of sales supervisor relationships on work meaning: The case of Canadian and Chinese salespersons. Industrial Marketing Management, 39, 7, 1069-1077.

Frodeman, R. (1996). Envisioning the Outcrop. Journal of Geoscience Education, 44, 417-427

Garud, R. \& Karnøe, P. (2003). Bricolage versus breakthrough: Distributed and embedded agency in technology entrepreneurship. Research Policy, 32, 277-300.

Gerson, E. M. \& Star. S.L. (1986) Analyzing Due Process in the Workplace. ACM Transactions on Office Information Systems. 4 (3). 257-270.

Gieryn, T. F. (1983). Boundary-work and the demarcation of science from non-science: Strains and interests in professional ideologies of scientists. American Sociological Review, 48(6), 781-795.

Gronn, P. C. (1983). Talk as the work: The accomplishment of school administration. Administrative Science Quarterly, 2(8), 1-21.

Halinen, A. Salmi, A. \& Havila, V. (1999). From dyadic change to changing business networks: An analytical framework. Journal of Management Studies, 36 (6) 779-794

Harrison, D., \& Kjellberg, H. (2010). Segmenting a market in the making: Industrial market segmentation as construction. Industrial Marketing Management, 39(5), 784-792.

Hedaa, L., \& Törnroos, J. Å. (2008). Understanding event-based business networks. Time \& Society, 17(2-3), 319-348.

Herepath, A. (2014). In the loop: A realist approach to structure and agency in the practice of strategy. Organization Studies, 35, 857-879.

Johnson, J.S \& Sohi, R. S. (2017) Getting business-to-business salespeople to implement strategies associated with introducing new products and services. Industrial Marketing Management, 62, 137-149

Kalleberg, A.L. (2009). Precarious work, insecure workers: Employment relations in transition. American Sociological Review. 74(1): 1-22.

Latour, B. (1992). Where are the missing masses? The sociology of a few mundane artifacts, in Bijker, Wiebe E.; Law, John, Shaping technology/building society: studies in sociotechnical change, Cambridge, Massachusetts: MIT Press, 225-258.

Lawrence, T. B. Leca, B. \& Zilber, T.B. (2013). Institutional work: Current research, new directions and overlooked issues, Organization Studies, 34(8), 1023-1033. 
Lawrence, T. B., \& Suddaby, R. (2006). Institutions and institutional work. The Sage Handbook of Organization Studies, 215-254.

Leonardi, P.M. Barley S.R. (2008) Materiality and change: Challenges to building better theory about technology and organizing. Information and Organization, 18 (3), pp. 159-176.

Mason, K. Friesl, M. \& Ford, C.J. (2017) Managing to make markets: Marketization and the conceptualization work of strategic nets in the life science sector. Industrial Marketing Management, 67, 52-69.

Möller, K. (2010) Sense-making and agenda construction in emerging business networks How to direct radical innovation. Industrial Marketing Management, 39 (3), 361-371

Nardi, B.A. \& Engestrom, Y. (1999) A Web on the Wind: The Structure on Invisible Work. Computer Supported Cooperative Work (CSCW) 8(1-2)1-8.

Notteboom, T. \& Rodrigue, J-P. (2008). Containerisation, box logistics and global supply chains: The integration of ports and liner shipping networks. Maritime Economics \& Logistics, $10(1-2), 152-174$

Okhuysen, G.A. Lepak, D. Lee, K. Labianca, G. Smith, V. \& Steensma, H.K. (2015). Theories of work and working today. Academy of Management Review, 1, 6-17.

Orr, J. (1996) Talking about machines. An ethnography of a modern job, Cornell University press, NY: Itacha (1996).

Palmer, M., Medway, D. \& Warnaby, G. (2017). Theorising temporary spatial clusters and institutional boundary work in industrial marketing, Industrial Marketing Management. 61.104-113.

Palmer, M., Simmons, G., Robinson, P.R. \& Fearne, A. (2015). Institutional maintenance work and power preservation in business exchanges: Insights into industrial supplier workshops, Industrial Marketing Management. 48. 214-225.

Perkmann M, \& Spicer A, 2008, How are management fashions institutionalized? The role of institutional work, Human Relations, 61, 811-844

Phillips, N. \& Lawrence, T.B. (2012). The turn to work in organization and management theory: Some implications for strategic organization. Strategic Organization, 10(3) 223230 .

Pollock, N. (2005) When is a workaround? Conflict and negotiation in computer systems development. Science, Technology and Human Values. 30(4) 1-19.

Schmidt, K. \& Bannon, L. (1992) Taking CSCW Seriously: Supporting Articulation Work. Computer-Supported Cooperative Work (CSCW) 1(1), 7-40. 
Schmidt, K. (2010). 'Keep Up the Good Work!': The Concept of 'Work' in CSCW. in Kjeld Schmidt. M. Lewkowicz et al. (eds.), Proceedings of COOP 2010, Computer Supported. Cooperative Work.

Selznick, P. (1949) TVA and the grassroots. New York: Harper and Row.

Star, S.L. \& Strauss, A. (1999). Layers of Silence, Arenas of Voice: The Ecology of Visible and Invisible Work. Computer-Supported Cooperative Work (CSCW). 8 (1-2), 9-30.

Strauss, A. (1985) Work and the Division of Labor. The Sociological Quarterly. 26 (1). 1-19.

Strauss, A. (1988) The articulation of project work: an organizational process. The Sociological Quarterly. 29(2). 163-178.

Suchman, L. (1995). Making Work Visible. Communications of the ACM. 38 (9). 56-64.

Wijen, F., \& Ansari, S. (2007). Overcoming Inaction through Collective Institutional Entrepreneurship: Insights from Regime Theory. Organization Studies, 28,1079-1100.

Zietsma, C., \& Lawrence, T. B. (2010). Institutional work in the transformation of an organizational field: The interplay of boundary work and practice work. Administrative Science Quarterly, 55(2), 189-221. 